\title{
LABELISASI HALAL TERHADAP PERILAKU KONSUMEN DALAM MEMILIH PRODUK MAKANAN SESUAI HUKUM ISLAM
}

\section{Mulyani Toyo}

Universitas Muhammadiyah Makassar || email: toyomulyani@gmail.com

\begin{abstract}
Abstrak
Penelitian ini termasuk penelitian kuantitatif yang bertujuan untuk mengetahui Baggaimana Tanggapan tentang Labelisasi Halal di benak masyarakat dan dan memilih produk Makanan syar'ih dalam keputusan Pembelian. Penelitian ini terdiri dari tiga variabel, yaitu Labelisasi Halal, Perilaku Konsumen, dan Produk Makanan Syar'ih.

Pengambilan sample dalam penelitian ini berjumlah 66 orang, peneliti menggunakan skala kepribadian, lembar observasi berupa Pengisian angket oleh konsumen. Selanjutnya, data yang diperoleh melalui instrument tersebut kemudian diolah melalui analisis regresi linear berganda dengan bantuan aplikasi Partial Least Square (PLS).

Hasil penelitian menunjukkan bahwa hasil analisis inferensial yang menggunakan uji $t$ dengan rumus regresi linear berganda menunjukkan bahwa nilai $t$ hitung lebih besar dari pada nilai t table sehingga Ho ditolak dan $\mathrm{Ha}$ diterima. Artinya Pengaruh Labelisasi Halal terhadap perilaku konsumen memilih produk makanan Syar'ih sangat berpengaruh pada Masyarakat diKec. Tamalate Makassar (studi kasus kelurahan Mangasa). Berdasarkan uraian kesimpulan tersebut, sebagai bentuk implikasi dari penelitian ini diharapkan agar Masyarakat lebih memperhatikan lagi label halal pada produk makanan pada saat keputusan pembelian.
\end{abstract}

Kata Kunci: Labelisasi Halal, Produk Makanan Syar'ih, Keputusan Pembelian 


\begin{abstract}
This study includes quantitative research that aims to find out how the response to Halal labeling in the minds of the community and choosing the food product in the purchase decision. This study consists of three variables, namely Halal Labeling, Consumer Behavior, and Syar'ih Food Products.

Sampling in this study amounted to 66 people, researchers used a personality scale, observation sheets in the form of questionnaires by consumers. Furthermore, the data obtained through the instrument is then processed through multiple linear regression analysis with the help of a Partial Least Square (PLS) application.

The results showed that the results of inferential analysis using the t-test with multiple linear regression formula showed that the calculated $t$ value was greater than the t table value so that Ho was rejected and Ha was accepted. This means that the influence of Halal Labeling on consumer behavior in choosing Syar'ih food products is very influential on the community in Cec. Tamalate Makassar (the case study of Mangasa village). Based on these conclusions, as a form of the implication of this research, it is expected that the public will pay more attention to halal labels on food products at the time of purchase decisions.
\end{abstract}

Keywords: Halal Labeling, Syar'ih Food Products, Purchase Decisions

\section{PENDAHULUAN}

Komunitas Muslim di seluruh dunia telah membentuk segmen pasar yang potensial dikarenakan pola khusus mereka dalam mengkonsumsi suatu produk. Pola konsumsi ini diatur dalam ajaran Islam yang disebut dengan Syariat. Dalam ajaran Syariat, tidak diperkenankan bagi kaum muslim untuk mengkonsumsi produk-produk tertentu karena substansi yang dikandungnya atau proses yang menyertainya tidak sesuai dengan ajaran Syariat islam.

Ajaran tegas Syariat Islam untuk menghindari hal-hal yang dilarang oleh
Allah SWT dan melaksanakan apa saja yang diperintahkan membuat konsumen Muslim bukanlah konsumen yang permissive (serba membolehkan) dalam pola konsumsinya. Mereka dibatasi oleh ke-Halalan dan ke-Haraman yang dimuat dalam nash Al Qur'an dan AlHadist yang menjadi panduan utama bagi kaum muslimin.

Pemahaman yang semakin luas tentang agama membuat konsumen Muslimin semakin selektif dalam pemilihan produk yang dikonsumsi. Khusus di Indonesia, Konsumen Muslim dilindungi oleh Lembaga yang 


\section{J-HES}

Jurnal Hukum Ekonomi Syariah

Volume 3, No. 1, Juli-Desember 2019 | p-ISSN: 2549-4872 | e-ISSN: 2654-4970

secara khusus bertugas untuk 168:

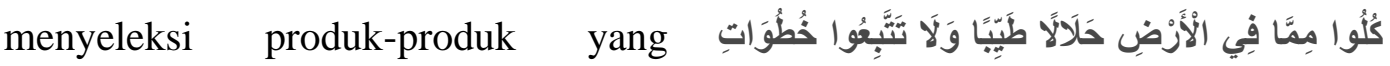

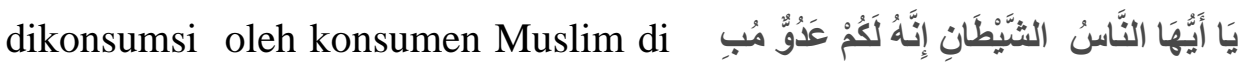

Indonesia. Lembaga ini adalah Terjemahnya:

Lembaga Pengkajian pangan, Obat- 'Wahai sekalian manusia, obatan dan kosmetika Majelis Ulama makanlah yang halal lagi baik Indonesia (LPPOM MUI). Lembaga ini mengawasi Produk yang beredar di masyarakat dengan cara memberikan sertifikat Halal sehingga produk yang sudah memiliki sertifikat halal dapat memberi label halal pada produknya.

Dalam Islam, konsumsi tidak dapat dipisahkan dari peranan keimanan. Peranan keimanan menjadi tolok ukur penting karena keimanan memberikan cara pandang dunia yang cenderung mempengaruhi kepribadian manusia, yaitu dalam bentuk perilaku, gaya hidup, selera, sikap-sikap terhadap sesama manusia, sumber daya, dan ekologi. Keimanan sangat dari apa yang terdapat di bumi, dan janganlah kamu mengikuti langkah-langkah syaitan; karena Sesungguhnya syaitan itu adalah musuh yang nyata bagimu”.

Ayat tersebut menjelaskan bahwa bukan hanya aspek halal dan haram saja yang menjadi batasan konsumsi dalam syariat Islam.Termasuk pula aspek yang mesti diperhatikan adalah makanan yang baik, cocok, bersih, dan tidak menjijikkan.

Kegiatan konsumsi barang yang halal merupakan sikap kepatuhan kepada perintah Allah sehingga memperoleh pahala. Pahala inilah yang dirasakan sebagai berkah dari barang dan jasa yang dikonsumsi. Demikian mempengaruhi sifat, kuantitas, dan kualitas konsumsi, baik dalam bentuk kepuasan material maupun spiritual. Inilah yang disebut sebagai bentuk upaya meningkatkan keseimbangan antara orientasi duniawi dan ukhrawi (Muflih Muhammad, 2006: 13).

Batasan konsumsi dalam Islam pula sebaliknya, konsumen tidak akanmengkonsumsi barang dan jasa yang haram karena itu adalah perbuatan dosa yang akan mendatangkan siksa dari Allah. Karena keberkahan yang diperoleh menjadi bernilai negative (Karra Muslimin, 2000: 101).

Kegiatan-kegiatan ekonomi sebagaimana dalam Q.S. Al-Baqarah: meliputi produksi, konsumsi, dan 
pertukaran yang menyangkut maslahah, harus dikerjakan sebagai suatu religious duty atau ibadah. Tujuannya bukan hanya untuk kepuasaan didunia tapi juga kesejahteraan diakhirat. Semua aktivitas tersebut yang memiliki maslahah bagi umat manusia, disebut needs atau kebutuhan dan semua kebutuhan ini harus dipenuhi (Nasution Edwin Mustafa, 2006: 63).

Islam banyak memberi kebebasan individual kepada manusia dalam masalah konsumsi dengan ketentuan tidak melanggar batas-batas kesucian. Walaupun begitu, kebebasan yang dimaksud disini terbatas pada barangbarang yang baik dan suci saja. Batasan tersebut tidak memberi kebebasan kepada kaum muslimin membelanjakan harta mereka atas barang-barang yang tidak bermanfaat bagi kesejahteraan masyarakat (Rahman Afjafur Rahman, 2010: 177).

Konsumen muslim akan lebih dekat dari garis konsumsi yang benar jika ia semakin komitmen dengan kaidah-kaidah konsumsi. Akan tetapi pengawasan internal seringkali lemah dalam merealisasikan komitmen individu. Inilah yang menuntut keharusan adanya pengawasan eksternal yang dilakukan oleh Negara dan umat, dan melakukan cara-cara yang beragam dengan menghimbau individu agar selalu komitmen kepada kaidah-kaidah konsumsi, dan mencegah segala bentuk penyelewengan dari garis konsumsi yang benar (Jaribah bin Ahmad Alharitshi, 2010: 177).

Ayat yang memerintahkan orangorang beriman untuk mengkonsumsi makanan yang halal dan berhati-hati dalam memilih makanan yang hendak dikonsumsinya, dan selalu berupaya meraih karunia Allah.Terkandung dalam Q.S. Al-Maidah ayat 88 :

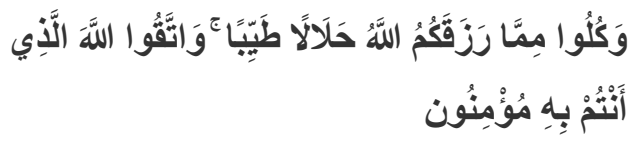

Terjemahnya:

'Dan makanlah makanan yang halal lagi baik dari apa yang Allah telah rezekikan kepadamu, dan bertakwalah kepada Allah yang kamu beriman kepadaNya”.

Ayat tersebut telah menyuruh kita hanya memakan makanan yang halal dan baik saja. Dua kesatuan yang tidak bisa dipisahkan, yang dapat diartikan halal dari segi syariah dan baik dari segi kesehatan, gizi, dan lainnya.

Label halal yang terdapat pada kemasan produk, akan mempermudah konsumen untuk mengidentifikasi suatu 


\section{J-HES}

Jurnal Hukum Ekonomi Syariah

Volume 3, No. 1, Juli-Desember 2019 | p-ISSN: 2549-4872 | e-ISSN: 2654-4970

produk. Berdasarkan perjalanan sejarah pemberlakuan halal di Indonesia LPPOM MUI adalah lembaga yang memelopori pemberian sertifikasi halal yang pertama dan masih dianggap satusatunya di Indonesia (Apriyanto, Anton dan Nurbowo, 2003: 36).

Beberapa tujuan diberlakukannya liberalisasi dan sertifikasi halal, antara lain sebagai berikut:

1. Jumlah penduduk Indonesia yang lebih dari $88 \%$ beragama Islam merupakan potensi pasar yang cukup besar bagi produk-produk halal. Apabila produk dalam negeri belum mampu menerapkan sistem produksi halal, maka akan dimanfaatkan oleh produk negara lain yang telah menerapkan sistem produk halal.

Karena belum memasyarakatnya sistem produksi halal di dalam negeri, maka impor seperti makanan akan menjadi ancaman bagi daya saing produk dalam negeri baik pasar lokal nasional, maupun pasar bebas.

Produk-produk olahan, baik makanan, minuman, obat-obatan, maupun kosmetika, kiranya dapat dikategorikan kedalam kelompok musytabihat syubhat (mengandung unsur ketidakjelasan atau masihsamar).
Apalagi jika produk tersebut berasal dari negeri yang penduduknya mayoritas non-muslim, sekalipun bahan bakunya berupa barang suci dan halal. Sebab, tidak tertutup kemungkinan dalam proses pembuatannya tercampur atau menggunakan bahan-bahan haram atau tidak suci.

Dengan demikian, produk olahan tersebut bagi umat Islam jelas bukan merupakan persoalan sepele, tetapi merupakan persoalan besar dan serius. Agar para produsen lebih total dan serius dalam melayani tuntutan konsumen akan kebutuhan produk yang Islami dan halal, maka sangat dibutuhkan suatu informasi berkesinambungan dari umat Muslim. Masih banyak perusahaan besar yang mencantumkan label halal pada maanan haramnya (Husen Ahmad, 2006: 126).

Atas dasar uraian tersebut di atas maka penulis tertarik untuk mengadakan penelitian mengenai "Pengaruh Labelisasi halal Terhadap Perilaku Konsumen Memilih Produk Makanan sesuai hukum Isam" (studi kasus warga Kelurahan Mangasa

Makassar). 


\section{METODE PENELITIAN}

Jenis penelitian yang digunakan kuantitatif, dengan pendekatan statistik deskriptif. Melalui penelitian ini dapat diketahui pengaruh labelisasi terhadap perilaku konsumen memilih produk makanan pada warga Kelurahan Mangasa Kecamatan Tamalate Makassar.

\section{Jenis Penelitian}

Penelitian ini merupakan penelitian lapangan, karena data diperoleh dari hasil pengamatan langsung pada warga Kelurahan Mangasa Kecamatan Tamalate Makassar. dengan menggunakan skala likert 5 point.

\section{Penelitian Kuantitatifadalah} penelitian ilmiah yang sistematis terhadap bagian-bagian dan fenomena serta hubungan-hubungannya.Tujuan penelitian kuantitatif adalah mengembangkan dan menggunakan model-model matematis, teori-teori dan / atau hipotesis yang berkaitan dengan fenomena alam. Proses pengukuran adalah bagian yang sentral dalam penelitian kuantitatif karena hal ini memberikan hubungan yang fundamental antara pengamatan empiris dan ekspresi matematis dari hubunganhubungan kuantitatif.

\section{Metode Analisis Data}

Analisis data dilakukan dengan cara analisis kuantitatif dengan menggunakan metode Partial Least Square (PLS), yaitu suatu metode yang berbasis keluarga regresi yang dikenalkan oleh Herman O.A Wold untuk penciptaan dan pembangunan model dan metode untuk ilmu - ilmu sosial dengan pendekatan yang berorientasi pada prediksi. PLS memilki asumsi data penelitian bebas distribusi (Distribution - Free), artinya data penelitian tidak mengacu pada salah satu distribusi tertentu (misalnya distribusi normal). PLS merupakan metode alternative dari Structural Equation Modeling (SEM) yang dapat digunakan untuk mengatasi permasalahan hubungan diantara variabel yang kompleks namun ukuran sampel datanya kecil (30 sampai 100), mengingat SEM memiliki ukuran sampel data minimal (Hair et.al., 2010).

PLS digunakan untuk mengetahui kompleksitas hubungan suatu kontsrak dan konstrak yang lain, serta hubungan suatu konstrak dan indikator indikatornya. PLS didefenisikan oleh 


\section{J-HES}

Jurnal Hukum Ekonomi Syariah

Volume 3, No. 1, Juli-Desember 2019 | p-ISSN: 2549-4872 | e-ISSN: 2654-4970

dua persamaan, yaitu inner model dan outer model.Inner model menentukan spesifikasi hubungan antara suatu konstrak dan konstrak yang lain, sedangkan outer model menentukan spesifikasi hubungan antara konstrak dan indikator - indikatornya.

Konstrak terbagi menjadi dua yaitu konstrak eksogen dan konstrak endogen.Konstrak eksogen merupakan konstrak penyebab yaitu, konstrak yang tidak dipengaruhi oleh konstrak lainnya.Konstrak eksogen memberikan efek kepada konstrak lainnya, sedangkan konstrak endogen merupakan konstrak yang dijelaskan oleh konstrak eksogen.Konstrak endogen adalah efek dari konstrak eksogen (Yamin dan Kurniawan, 2009).

PLS dapat bekerja untuk model hubungan konstrak dan indikator indikatornya yang bersifat reflektif dan formatif, sedangkan SEM hanya bekerja pada model hubungan yang bersifat reflektif saja (Ghazali, 2006).

\section{HASIL DAN PEMBAHASAN}

\section{Analisis Data}

Model analisis yang dipergunakan dalam penelitian ini adalah analisis yang diperoleh dari pengguna Pengaruh Labelisasi Halal dan diolah dengan menggunakan XLSTAT, metode PLSPM.

\section{Menilai Outer Model (Model Pengukuran) \\ Evaluasi Outer Model} mendefinisikan bagaimana setiap blok indikator berhubungan dengan variabel latennya. Sebagaimana gambar 4.1 dibawah ini menunjukkan indicator reflektif Model pengukuran atau outer model dengan indikator reflektif di evaluasi dengan Convergent dan decriment validity. Untuk validitas indikator dapat dilihat dari nilai loading faktor (standardized loading) nilai ini mengambarkan besarnya korelasi antara tiap indicator valid bila memiliki nilai standardized loading lebih dari 0,5. Berdasarkan loading factor correlation (dimension). Untuk Evaluasi confergent validity meliputi reliability (validitas indikator) reliability variabel dimulaiAverage Varibel Extrated (AVE). 
Tabel 1

Correlations (Dimension 1):

\begin{tabular}{|c|c|c|c|c|c|}
\hline Laten variabel & $\begin{array}{l}\text { Manifest } \\
\text { Variables }\end{array}$ & $\begin{array}{l}\text { Standardized } \\
\text { Loading }\end{array}$ & Loadings & Locations & $\begin{array}{l}\text { Commmuna } \\
\text { Lities }\end{array}$ \\
\hline $\begin{array}{l}\text { LABELISASI } \\
\text { HALAL }\end{array}$ & $\begin{array}{l}\mathrm{X} 1 \\
\mathrm{X} 2 \\
\mathrm{X} 3\end{array}$ & $\begin{array}{l}0,721 \\
0,866 \\
0,839\end{array}$ & $\begin{array}{l}0,409 \\
0,735 \\
0,715\end{array}$ & $\begin{array}{l}0,000 \\
0,000 \\
0,000\end{array}$ & $\begin{array}{l}0,520 \\
0,750 \\
0,703\end{array}$ \\
\hline $\begin{array}{l}\text { PERILAKU } \\
\text { KONSUMEN }\end{array}$ & $\begin{array}{l}\mathrm{X} 4 \\
\mathrm{X} 5\end{array}$ & $\begin{array}{l}0,662 \\
0,819\end{array}$ & $\begin{array}{l}0,392 \\
0,432\end{array}$ & $\begin{array}{l}0,000 \\
0,000\end{array}$ & $\begin{array}{l}0,438 \\
0,671\end{array}$ \\
\hline $\begin{array}{l}\text { PRODUK } \\
\text { MAKANAN } \\
\text { SYAR'IH }\end{array}$ & $\begin{array}{l}\mathrm{Y} 1 \\
\mathrm{Y} 2\end{array}$ & $\begin{array}{l}0,842 \\
0,718 \\
0,407\end{array}$ & $\begin{array}{l}0,597 \\
0,377 \\
0,207\end{array}$ & $\begin{array}{l}0,000 \\
0,000 \\
0,000\end{array}$ & $\begin{array}{l}0,709 \\
0,515 \\
0,166\end{array}$ \\
\hline
\end{tabular}

Sumber: data olah dengan menggunakan PLS-PM

Berdasarkan tabel $1 \mathrm{di}$ atas dapat mempengaruhi variabel (Labelisasi dilihat bahwa nilai indikator yang miliki Halal ).

korelasi dengan variabel bank adalah dimana nilai standardized loading untuk indikator:

$X_{1}=0,721>0,5$,

$X_{2}=0,866>0,5$

$X_{3}=0,839>0,5$

Ini menunjukkan indikator Masyarakat $\left(X_{1}\right)$, Produsen $\left(X_{2}\right)$ dan LPPOM MUI $\left(X_{3}\right)$ valid karena nilai Kemudian untuk melihat nilai indikator yang memiliki korelasi dengan variable perilaku konsumen adalah berdasarkan loading factor correlation (dimension) di mana nilai standardized loading di atas maka nilai indikatornya adalah:

kuadrat di setiap standardized

$X 4=0,662>0,5$

$X_{5}=0,819>0,5$ loading.Untuk nilai communalities $X_{1}=$ Ini menunjukkan indikator 0,520 artinya $90 \%$ tidak valid dan $X_{2}$ $=0,750$ dan $X_{3}=0,703$ ini membuktikan dari ketiga indikator $\left(X_{1}, X_{2}, X_{3}\right)$ terlihat bahwa $X_{2}$ lebih dominan membeli $\left(\mathbf{X}_{4}\right)$, kepuasaan konsumen dalam membeli $\left(\mathbf{X}_{5}\right)$, valid nilai kuadrat disetiap standardized loading. Nilai communalities $\mathbf{X}_{4}=0,438$ artinya $\%$ tidak valid indikator $X 4$ tidak mampu dijelaskan dalam konstan perilaku 


\section{J-HES}

Jurnal Hukum Ekonomi Syariah

Volume 3, No. 1, Juli-Desember 2019 | p-ISSN: 2549-4872 | e-ISSN: 2654-4970

konsumen, demikian pula $\mathbf{X}_{5}$ adalah $0,671 \%$,ini membuktikan bahwa indikator $\mathbf{X}_{5}$ lebih dominan mempengaruhi Variabel Perilaku konsumen.

Kemudian untuk melihat nilai indikator yang memiliki korelasi dengan variabel produk makanan syar'ih adalah Berdasarkan loading factor correlation (dimension) dimana nilai standardized loading diatas maka nilai indikatornya adalah:

$\mathbf{Y}_{1}=0,842>0,5$

$\mathbf{Y}_{2}=0,718>0,5$

$\mathbf{Y}_{3}=0,407>0,5$

Ini menunjukkan indicator berlabel halal $\left(\mathbf{Y}_{1}\right.$, kontrol proses produksi $\left(\mathbf{Y}_{2}\right.$ valid karena nilai kuadrat disetiap standardized loading. Sedangkan tidak mengandung unsur haram $\left(\mathbf{Y}_{3}\right)$ tidak valid. Nilai communalities $\mathbf{Y}_{1}=0,709$ artinya $\%$ valid indikator $\left(\mathbf{Y}_{1}\right)$ mampu dijelaskan dalam variabel produk makanan syar'ih, demikian pula $\mathbf{Y}_{2}$ dan $\mathbf{Y}_{3}$ masing-masing $0,515 \%$ dan $0,166 \%$ ini membuktikan dari kedua indicator tidak valid.Maka diantara indikator $\left(\mathbf{Y}_{1}, \mathbf{Y}_{2}, \mathbf{Y}_{3}\right)$ terlihat bahwa $\mathbf{Y}_{1}$ lebih dominan mempengaruhi variabel produk makanan syar'ih.

Untuk mengukur atau menguji nilai loading faktor di indikator dilihat pengukuran dari hasil Critical Ratio (CR) pengukuran ini dari hasil nilai standardized loading yang diperoleh dari bostrapping dengan standar caranya $\mathrm{CR}=$ nilai Statistik, maka dapat dilihat dari loading factor Composit Reliability.

\section{Uji Reliabilitas (Konsisten Internal)}

Indicator akan valid berdasarkan dari olah data dengan nilai Crombach's Alpha untuk variabel berada di atas 0,70 sedangkan nilai Composite Reliability adalah (D.G. rho). Masing-masing Labelisasi halal 0,865, Perilaku konsumen 0,701 Produk makanan syar'ih 0,735 , ini menunjukkan reliability dapat di andalkan, atau saling berpengaruh terhadap variabel sebagaimana table berikut: 
Tabel 2

Composite reliability:

\begin{tabular}{lccc}
\hline \multicolumn{1}{c}{$\begin{array}{c}\text { Latent } \\
\text { Variable }\end{array}$} & Dimensions & $\begin{array}{c}\text { Cronbach } \\
\text { Alpha }\end{array}$ & $\begin{array}{c}\text { D.G. rho } \\
\text { (PCA) }\end{array}$ \\
\hline $\begin{array}{l}\text { LABELISASI } \\
\text { HALAL }\end{array}$ & 3 & 0,743 & 0,865 \\
\hline $\begin{array}{l}\text { PERILAKU } \\
\text { KONSUMEN }\end{array}$ & 2 & 0,201 & 0,701 \\
\hline $\begin{array}{l}\text { PRODUK } \\
\text { MAKANAN }\end{array}$ & 3 & 0,434 & 0,735 \\
SYAR'IH & & & \\
\hline
\end{tabular}

Sumber : data olah dengan menggunakan PLS-PM.

\section{Uji Model Assessment (Penilaian)}

Tabel 3

Model assessment (Dimension 1):

\begin{tabular}{cccccc}
\hline $\begin{array}{c}\text { Latent } \\
\text { Variable }\end{array}$ & Type & $\begin{array}{c}\text { Mean } \\
\text { (manifest } \\
\text { variables) }\end{array}$ & $R^{2}$ & $\begin{array}{c}\text { ADJUSTED } \\
R^{2}\end{array}$ & $\begin{array}{c}\text { Mean } \\
\text { Communa } \\
\text { Lities (AVE) }\end{array}$ \\
\hline $\begin{array}{c}\text { LABELISASI } \\
\text { HALAL }\end{array}$ & Exogenous & 0.000 & & & 0,658 \\
\hline $\begin{array}{c}\text { PERILAKU } \\
\text { KONSUMEN }\end{array}$ & Endogenous & 0.000 & 0.139 & 0.139 & 0,555 \\
\hline $\begin{array}{c}\text { PRODUK } \\
\text { MAKANAN } \\
\text { SYAR'IH }\end{array}$ & Endogenous & 0.000 & 0.363 & 0.353 & 0,464 \\
\hline \multicolumn{1}{c}{ Mean } & & 0,251 & & 0,559 \\
\hline
\end{tabular}

Sumber : data olah dengan menggunakan PLS-PM

Berdasarkan tabel 3 di atas, dapat makanan syar'ih 0,464, Dari data dilihat bahwa nilai AVE(Average tersebut terdapat satu variabel yaitu Varibel Extrated) dari masing-masing Labelisasi Halal, nilai AVE variabel variabel untuk Labelisasi halal 0,658 tersebut lebih besar dari 0.5 maka Perilaku konsumen 0,555 , Produk sifatnya convergent validity yang baik. 


\section{J-HES}

Jurnal Hukum Ekonomi Syariah

Volume 3, No. 1, Juli-Desember 2019 | p-ISSN: 2549-4872 | e-ISSN: 2654-4970

\section{Descriminant Validity}

Tabel 4

Cross-Loadings (Monofactorial Manifest Variables)

\begin{tabular}{cccc}
\hline & $\begin{array}{c}\text { LABELISASI } \\
\text { HALAL }\end{array}$ & $\begin{array}{c}\text { PERILAKU } \\
\text { KONSUMEN }\end{array}$ & $\begin{array}{c}\text { PRODUK } \\
\text { MAKANAN } \\
\text { SYAR'IH }\end{array}$ \\
\hline $\mathrm{X} 1$ & 0,721 & 0,239 & 0,335 \\
\hline $\mathrm{X} 2$ & 0,866 & 0,351 & 0,453 \\
\hline $\mathrm{X} 3$ & 0,839 & 0,289 & 0,350 \\
\hline $\mathrm{X} 4$ & 0,108 & 0.662 & 0,819 \\
\hline $\mathrm{X} 5$ & 0,411 & 0,819 & 0,394 \\
\hline $\mathrm{Y} 1$ & 0,286 & 0,362 & 0,842 \\
\hline $\mathrm{Y} 2$ & 0,493 & 0,447 & 0,718 \\
\hline $\mathrm{Y} 3$ & 0,188 & 0,251 & 0,407
\end{tabular}

Sumber : data olah dengan menggunakan PLS-PM

Berdasarkan tabel 4 di atas dapat standardized loading untuk indikator $X_{1}$ dilihat bahwa nilai indikator yang $=0,721, X_{2}=0,866, X_{3}=0,839$. Nilai memiliki korelasi dengan variabel masing-masing variabel $>0,5$.

Labelisasi halal adalah di mana nilai

\section{Uji Inner Model (Pengujian Model Struktural)}

Tabel 5

Path coefficients (Perilaku konsumen/1)

$\mathrm{R}^{2}$ (PERILAKU KONSUMEN / 1):

\begin{tabular}{cccccccc}
\hline$R^{2}$ & $\mathrm{~F}$ & $\operatorname{Pr}>\mathrm{F}$ & $\begin{array}{c}R^{2} \\
\text { (Bootstrap) }\end{array}$ & $\begin{array}{c}\text { Standard } \\
\text { error }\end{array}$ & $\begin{array}{c}\text { Critical } \\
\text { ratio } \\
(\mathrm{CR})\end{array}$ & $\begin{array}{c}\text { Lower } \\
\text { bound } \\
(95 \%)\end{array}$ & $\begin{array}{c}\text { Upper bound } \\
(95 \%)\end{array}$ \\
\hline 0,139 & 10,306 & 0,002 & 0,155 & 0,083 & 1,674 & 0,006 & 0,365 \\
\hline
\end{tabular}

Path coefficients (PERILAKU

KONSUMEN / 1):

\begin{tabular}{cccccccccc}
\hline $\begin{array}{c}\text { Latent } \\
\text { variable }\end{array}$ & Value & $\begin{array}{c}\text { Stand } \\
\text { ard } \\
\text { error }\end{array}$ & $\mathrm{T}$ & $\mathrm{Pr}>|\mathrm{t}|$ & $\mathrm{f}^{2}$ & $\begin{array}{c}\text { Value( } \\
\text { Bootst } \\
\text { rap) }\end{array}$ & $\begin{array}{c}\text { Standard } \\
\text { error(Boots } \\
\text { trap) }\end{array}$ & $\begin{array}{c}\text { Critical } \\
\text { ratio } \\
\text { (CR) }\end{array}$ \\
\hline $\begin{array}{c}\text { LABELIS } \\
\text { ASI }\end{array}$ & & & & & & & & \\
HALAL & 0,372 & 0,116 & 3,210 & 0,002 & 0,161 & 0,364 & 0,151 & 2,474 \\
\hline
\end{tabular}

Sumber : data olah dengan menggunakan PLS-PM.

Berdasarkan tabel path nilai t statistik untuk perilaku konsumen coefficients Labelisasi halal di mana 3,210 dengan $\mathrm{R}$ Value 0,372 bahwa 
dengan standar probability $0,002<0,05$ Labelisasi halal secara signifikan atau dari nilai Critical Rasio (CR) 2,474 mempunyai pengaruh positif terhadap sehingga dapat dikatakan bahwa bahwa variabel Perilaku konsumen.

Tabel 6

Path coefficients (Produk makanan syar'ih/1) $\mathrm{R}^{2}$ (PERILAKU KONSUMEN /

$1)$ :

\begin{tabular}{cccccccc}
\hline $\mathrm{R}^{2}$ & $\mathrm{~F}$ & $\operatorname{Pr}>\mathrm{F}$ & $\begin{array}{c}\mathrm{R}^{2} \text { (Bootstr } \\
\text { ap) }\end{array}$ & $\begin{array}{c}\text { Standar } \\
\text { d error }\end{array}$ & $\begin{array}{c}\text { Critical } \\
\text { ratio } \\
(\mathrm{CR})\end{array}$ & $\begin{array}{c}\text { Lower } \\
\text { bound } \\
(95 \%)\end{array}$ & $\begin{array}{r}\text { Upper } \\
\text { bound } \\
(95 \%)\end{array}$ \\
\hline 0,363 & 17,920 & 0,000 & 0,395 & 0,092 & 3,924 & 0,219 & 0,581 \\
\hline
\end{tabular}

Path coefficients (PRODUK MAKANAN SYAR'IH / 1):

\begin{tabular}{ccccccccc}
\hline Latent variable & Value & $\begin{array}{c}\text { Standard } \\
\text { error }\end{array}$ & $\mathrm{T}$ & $\mathrm{Pr}>|\mathrm{t}|$ & $\mathrm{f}^{2}$ & $\begin{array}{c}\text { Value } \\
\text { (Boots } \\
\text { trap) }\end{array}$ & $\begin{array}{c}\text { Standard } \\
\text { error(Boot } \\
\text { strap) }\end{array}$ & $\begin{array}{c}\text { Critical } \\
\text { ratio } \\
\text { (CR) }\end{array}$ \\
\hline $\begin{array}{c}\text { LABELISASI } \\
\text { HALAL }\end{array}$ & 0,332 & 0,108 & 3,061 & 0,003 & 0,149 & 0,348 & 0,087 & 3821 \\
\hline $\begin{array}{c}\text { PERILAKU } \\
\text { KONSUMEN }\end{array}$ & 0,394 & 0,108 & 3,635 & 0,001 & 0,210 & 0,760 & 0.097 & 4,079 \\
\hline
\end{tabular}

Sumber : data olah dengan menggunakan PLS-PM

\section{Berdasarkan tabel Path Makassar (studi Kasus warga}

coefficient Perilaku konsumen di mana

nilai $\mathrm{t}$ statistik untuk variabel produk makanan syar'ih 3,635 dan $\mathrm{R}$ value 0,394 bahwa dengan standar probability $0,000<0,05$ sehingga dapat di katakan bahwa secara signifikan mempunyai pengaruh positif terhadap variabel produk makanan syar'ih.

\section{Pembahasan Hasil Penelitian}

Hipotesis 1: Labelisasi Halal mempengaruhi perilaku konsumen dalam memilih produk Makanan pada warga di Kecamatan Tamalate

\section{kelurahan Mangasa).}

Hasil pengujian inner Model sebagaimana ditunjukkan di mana pada uji hubungan antar variabel dapat disimpulkan bahwa Labelisasi halal mempengaruhi Perilaku konsumen sebesar 3,210 signifikan pada 0,05 (T hitung lebih besar dari 1,671) dengan nilai.Diterimanya Hipotesis, Maka dapat disimpulkan bahwa pemahaman labelisasi halal berpengaruh secara signifikan terhadap perilaku konsumen dalam membeli produk makanan berlabel halal pada masyarakat di 
kecamatan Tamalate Makassar (studi bahwa Masyarkat di Kelurahan kasus warga Kelurahan Mangasa), Mangasa sebagian besar sudah pengaruhnya positif. Hal ini memahami pentingnya produk mengandung Arti bahwa semakin tinggi Makanan syar'ih bagi umat muslim adanya pemahaman di benak konsumen sehingga sangat memperhatikan label tentang pentingnya Labelisasi Halal halal dalam keputusan pembelian pada suatu produk Makanan yang produk makanan, perkembengan dikonsumsi oleh Umat Islam Maka Masyarakat intelektual muslim di semakin tinggi Masyarakat Indonesia semakin pesat khususnya di memperhatikan labelisasi Halal pada kota Makassar. Masalah halal dan produk ketika berbelanja.

Hipotesis 2: Perilaku konsumen mempengaruhi labelisasi Halal dalam memilih produk makan syar'ih dalam Keputusan Pembelian

Hasil pengujian inner Model sebagaimana ditunjukkan dalam Loading factor di mana pada uji hubungan antar variabel menunjukan bahwa variabel Perilaku konsumen mepengaruhi Produk Makanan syar'ih yaitu sebesar 3,635 signifikan pada 0,05 (T hitung lebih besar dari 1,671). Hal ini berarti dapat di simpulkan bahwa perilaku konsumen secara signifikan berpengaruh terhadap keputusan pembelian produk makanan syar'ih pada Masyarakat di Kecamatan Tamalate Makassar (studi kasus warga kelurahan Mangasa), Ini menunjukan haram bagi Islam adalah sesuatu yang penting dan telah menjadi bagian dari keimanan dan ketaqwaan,konsumen semakin menjadi kritis tidak hanyamenuntuk produk makanan yang higenis, terjamin kandugan gizinya namun Label halal dan Produk Makanan syar'ih menjadi kunci dalam keputusan pembelian.

\section{KESIMPULAN}

Berdasarkan dari hasil analisis dan pembahasan yangdi lakukan penulis sebelumnya, Maka Kesimpulan yang dapat ditarik penulis Adalah:

1. Bahwa variabel labelisasi halal berpengaruh langsung dan signifikan terhadap variabel Perilaku konsumen (data diolah terlampir). 
2. Analisis dari hasil perhitungan hukum islam mengenai segala sesuatu yang peneliti lakukan adalah di bidang Muamalah adalah adanya pengaruh antara labelisasi diperbolehkan, Selama tidak ada halal terhadap perilaku konsumen larangan syara' yang memilih memilih produk makanan mengharamkannya. Demikian pula dalam kemasan pada warga di dengan pengkonsumsian makanan, Kecamatan Tamalate Makassar semuajenis makanan asalnya (studi warga kelurahan Mangasa) diperbolehkan kecuali secara tegas dengan pengaruh sebesar 37,2\% diharamkan baik di dalam al-Qur'an atau berukuran sedang, maupun Hadist. Tujuan Hukum islam Bahwa Variabel Perilaku tidak lain adalah untuk Kemaslahatan

Konsumen berpengaruh dan signifikan terhadap variabel Produk Makanan Syar'ih (data diolah terlampir). Aspek manusia, Makanan yang halal dan thayyib sudah tentu akan membawa manfaat lahir bathin bagi manusia.

\section{DAFTAR PUSTAKA}

Al-Haritsi, Jaribah bin Ahmad. Fiqih Ekonomi Umar bin Al-Khattab. Jakarta Timur: Khalifa. 2010.

Karra Muslimin, dkk. Pengantar Ekonomi Islam. Makassar : Alauddin Press. 2000.

Nasution, Edwin Mustafa. Pengenalan Eksklusif Ekonomi Islam. Jakarta: Kencana. 2006.

AfZafur Rahman, Dokrin Ekonomi Islam jilid 2 (Jakarta: Dona Bakti Wakaf,1995), 2010.

Apriyanto, Anton dan Nurbowo. Panduan Belanja dan Konsumsi Halal. Jakarta pers: Khairun Bayan. 2003.

Charles, Lamb. Pemasaran . Jakarta: Salemba empat, 2001.

Handoko Hani dan Swastha, Manajemen Pemasaran : Analisa Perilako Konsumen Yogyakarta: BPFE, 2000.

Dewi, Diana Candra. Rahasia Dibalik Makanan Haram. Malang: UIN Press. 2007.

Departemen Agama RI. Sistem dan Prosedur Penetapan Fatwa Produk Halal MUI. Jakarta: Depag. 2003.

Girindra, Aisyah dan Ali Yafie. Bahaya Makanan Haram Bagi Kesehatan Jasmani dan Kesehatan Rohani. Jakarta: Al-Mawardi Prima. 2003. 


\section{J-HES}

Jurnal Hukum Ekonomi Syariah

Volume 3, No. 1, Juli-Desember 2019 | p-ISSN: 2549-4872 | e-ISSN: 2654-4970

Kadir, Amiruddin. Ekonomi dan Keuangan Syariah. Makassar: Alauddin University Press.

Muhflih, Muhammad. Perilaku Konsumen dalam Perspektif Ilmu Ekonomi Islam. Jakarta: PT Raja Grafindo. 2006.

Sakr, Ahmad Hussein. Menyingkap Produk-Produk Haram. Yogyakarta: Wahana Cendikia. 2006. 